\title{
EVALUATION OF MECHANICAL AND PHYSICOCHEMICAL PROPER- TIES OF PROTECTION COATINGS OBTAINED BY SOL-GEL METHOD
}

\author{
M. TKACZYK, J. KRZAK-ROS, J. KALETA
}

\author{
Institute of Materials Science and Applied Mechanics Wroclaw University of Technology, Poland
}

Thin coatings, obtained by the sol-gel method, could find potential applications in medical, chemical and food industry. To achieve this, coatings need to have proper physicochemical, mechanical and protective properties. Titanium dioxide $\left(\mathrm{TiO}_{2}\right)$ and silicon dioxide $\left(\mathrm{SiO}_{2}\right)$ coatings have been applied onto the surface of a stainless steel $(316 \mathrm{~L})$ by the solgel method using two techniques: dip-coating and painting. To determine the physicochemical composition of triple $\mathrm{SiO}_{2}$ and $\mathrm{TiO}_{2}$ coatings, samples were examined by Raman spectroscopy. Surface images obtained with the use of a scanning electron microscopy allow us to determine the surface morphology and continuity of the coatings. The surface morphology was examined before and after tensile tests. The static tensile tests and fatigue strength tests were conducted on a hydraulic testing machine MTS 810 with a measuring range of up to $100 \mathrm{kN}$. A preliminary research has confirmed that the coatings obtained by the sol-gel method have physicochemical, mechanical and protective properties that make it possible to use them as protective coatings.

Key words: sol-gel thin film, titanium dioxide, silicon dioxide, protective coating, aging of hydrolysate.

Ceramic materials have better corrosion, wear and creep resistance and lower chemical reactivity than metallic materials [1]. These properties make them valuable in applications such as protective coatings on metallic substrates $[1,2]$.

Several methods have been used to obtain ceramic coatings on metallic surfaces: physical vapour deposition, chemical vapour deposition, plasma spraying, laser cladding, chemical plating or sol-gel process [3]. Out of all the methods, the sol-gel process seems to be the most promising. The fundamental advantage of the sol-gel process is the possibility to form ceramic materials and glasses at a temperature close to room temperature $[4,5]$. Preparing glass in a traditional way requires melting of the precursors at high temperature, which restrains the choice of substances that can be entrapped in/or onto the glass products. It is possible to place many products inside the sol-gel materials, for example: nanoparticles of metals, chemical substances, drugs or even some bacteria [6]. Furthermore, the sol-gel process is clean, environmentally friendly and cost-effective [7]. The sol-gel method is based on the hydrolysis of liquid precursors and formation of colloidal sols. This method allows us to obtain materials of high purity and excellent homogeneity of the microstructure. Depending on the choice of reagents, the annealing method, the method of layering and doped substances, one could obtain powders, blocks or thin coatings (Fig. 1) with a broad spectrum of opti$\mathrm{cal}$, electronic, magnetic, electrochemical properties and with a desired porosity of materials. Coatings obtained by the sol-gel method could be applied in electronics as coatings for semiconductors or conductive anodes. Their anti-reflective properties could be used in optics. Because of their soundproofing, scratch-resistance, abrasive or preventive properties, the coatings could be used as protective coatings [4]. The biotolerant coatings could be applied as protective coatings for medical implants $[8,9]$.

Corresponding author: J. KALETA, e-mail: Jerzy.Kaleta@pwr.wroc.pl 


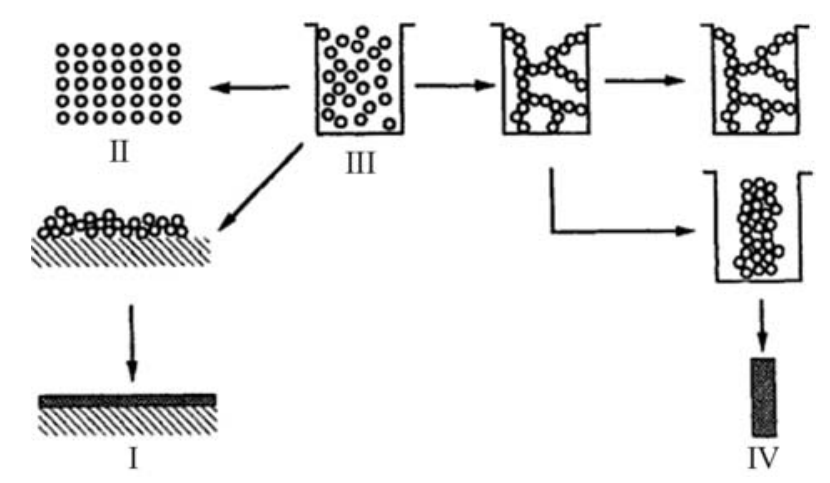

Fig. 1. Scheme for the preparation of sol-gel materials.

In the presented work the researches were conducted with the aim to obtain continuous $\mathrm{TiO}_{2}$ and $\mathrm{SiO}_{2}$ thin coatings on metallic substrates $(316 \mathrm{~L})$ by the sol-gel method and to determine their protective and mechanical properties.

Experimental details. The substrates used in this work were made from a stainless steel (316L) with different shapes (Fig. 2 and Fig. 3), depending on the kind of research.

Prior to dip coating, the substrates were rinsed with water and then subjected to ultrasonic cleaner with acetone for $15 \mathrm{~min}$ in order to remove any organic matter and dust which might have been present on the surface. Afterwards the substrates were rinsed with distilled water, then with ethanol and left to dry.

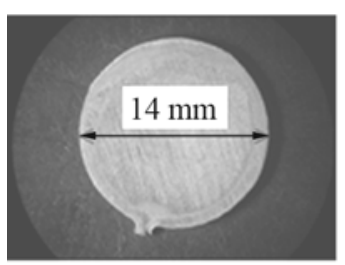

Fig. 2.

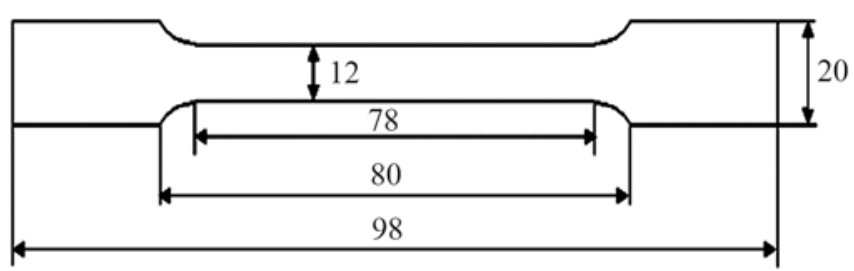

Fig. 3.

Fig. 2. Light microscope image showing the shape and dimensions of substrates for Raman spectroscopy and electrochemical studies.

Fig. 3. Shape and dimensions of substrates for tensile tests.

Silicon dioxide $\left(\mathrm{SiO}_{2}\right)$ coatings have been acquired from hydrolysates which were created using TEOS $\left(\left[\mathrm{Si}\left(\mathrm{OC}_{2} \mathrm{H}_{5}\right)_{4}\right]\right), \mathrm{EtOH}\left(\left[\mathrm{C}_{2} \mathrm{H}_{5} \mathrm{OH}\right]\right)$ and $\mathrm{HCl}$. To obtain titanium dioxide $\left(\mathrm{TiO}_{2}\right)$ coatings, TiPO $\left.\left(\left[\mathrm{TiCOC}_{3} \mathrm{H}_{7}\right)_{4}\right]\right)$, izoPrOH $\left(\left[\mathrm{C}_{3} \mathrm{H}_{7} \mathrm{OH}\right]\right.$ and AcAc $\left[\mathrm{C}_{5} \mathrm{H}_{8} \mathrm{O}_{2}\right]$ were used.

The coatings were deposited onto the surface of a stainless steel (316L) substrates using two techniques: dip coating and painting. Dip coating is based on dipping the substrate into the hydrolysate. In this paper, the immersion speed was $34.26 \mathrm{~mm} / \mathrm{min}$ and the retention time (time after immersion of the substrate and before the start of extraction), depended on the number of the superimposed layer.

The first-layer substrates were kept in the hydrolysate for $60 \mathrm{~s}$. When applying the second and third layers on the same substrate the retention time was respectively: $30 \mathrm{~s}$ and $15 \mathrm{~s}$. The retention time was reduced to minimize the dissolution of the already formed layers in the hydrolysate. In the painting technique the hydrolysate was applied onto the substrates by a paintbrush. After superimposing each layer the samples were dried in air for $24 \mathrm{~h}$. The last step to obtain the coatings was annealing at $500^{\circ} \mathrm{C}$ for $1 \mathrm{~h}$.

To determine the physicochemical composition of triple layer $\mathrm{SiO}_{2}$ and $\mathrm{TiO}_{2}$ coatings, samples were examined with the use of Raman spectroscopy. Raman scattering of radiation was recorded in the range of $1950 \ldots 4000 \mathrm{~cm}^{-1}$. The coatings were obtained by the sol-gel method from fresh, one-week-old, two-week-old and three-weekold hydrolysates to examine the effect of aging of the hydrolysates on the chemical composition of the coatings. 
The surface morphology, microstructure and elemental composition were characterized by a Scanning Electron Microscope HITACHI S-3400 (SEM). SEM observations and Energy Dispersive X-Ray Spectroscopy (EDS) researches were carried out to examine the continuity of the obtained coatings and to compare a dip coating and painting techniques.

Corrosion tests of the coatings consisted of the salt spray tests and electrochemical studies. Preliminary studies of corrosion resistance - the salt spray tests - were done for coatings obtained by the painting technique to examine the efficiency of this method. The total time of the tests was $48 \mathrm{~h}$. Optical inspections of the coating surfaces were carried out after 24 and 48 hours of testing to monitor the formation of corrosion pitting. The electrochemical study consisted of recording the polarization curves in a three-electrode cell. The reference electrode was a saturated calomel electrode (NEK) while the auxiliary electrode was a platinum electrode. The measuring system consisted of a measurement vessel, SI1286 potentiostat and a computer. The examination was conducted in an artificial physiological fluid (SBF) in which the samples were immersed for $10 \mathrm{~min}$ before the test. The samples were polarized in the direction of the anode at a rate of $1 \mathrm{mV} / \mathrm{s}$, starting from the potential $(-1000 \mathrm{mV})$.

The study was performed to determine the effect of hydrolysate aging on the protective properties of $\mathrm{SiO}_{2}$ and $\mathrm{TiO}_{2}$ coatings.

The tensile tests were performed on an MTS 810 machine with the range of tensile stresses from 0 to $100 \mathrm{kN}$. The shape and dimensions of the samples are presented in Fig. 3. The thickness of the samples was $2 \mathrm{~mm}$. The studies consisted of static tensile tests and fatigue strength tests. The testing samples were substrates covered by single and triple layer $\mathrm{SiO}_{2}$ and $\mathrm{TiO}_{2}$ coatings obtained by the dip coating technique. Static tensile tests were performed in accordance to Polish Norm PN-EN 10002-1:2004 [10]. The extension speed was $0.3 \mathrm{~mm} / \mathrm{min}$ in the elastic range and was increased to $3 \mathrm{~mm} / \mathrm{min}$ after crossing the yield strength. The stress-strain graph for a sample covered with a single $\mathrm{SiO}_{2}$ coating is shown in Fig. 4. The graphs looked almost the same for all samples.

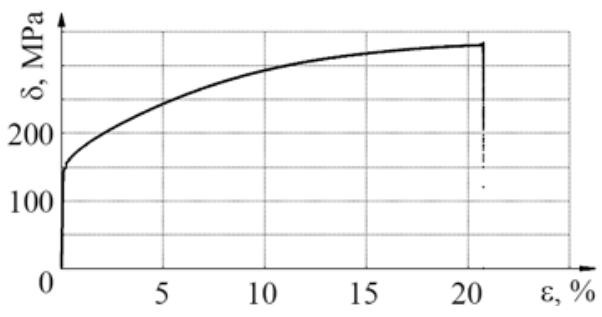

Fig. 4.

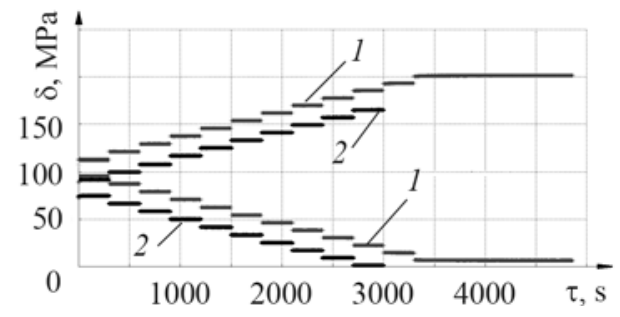

Fig. 5.

Fig. 4. Stress-strain graph for a sample covered with $\mathrm{SiO}_{2}$ coating.

Fig. 5. Graph of increasing cyclic tests. 1 - first test; 2 - second test.

Analysis of graphs obtained for the samples tested in the static tensile test and increasing cyclic tests (Fig. 5) were performed to select the appropriate values for the load and the frequency to perform the fatigue strength test. Because of the shape of samples, the values of the load should not lead to the compression of samples. Analysis of these data allowed us to choose the appropriate test parameters. The cyclic load was $4.5 / 1.5 \mathrm{kN}$ and the frequency $-10 \mathrm{~Hz}$. After tensile tests SEM analyses of the samples were conducted to verify the continuity of the coatings.

Results and discussion. Raman spectroscopy studies (Fig. 6) have shown that coatings obtained by the sol-gel method are crystalline $\mathrm{TiO}_{2}$ and amorphous $\mathrm{SiO}_{2}$. In addition, the studies by Raman spectroscopy demonstrated that aging of the hydroly- 
sates has not affected the chemical composition of the coatings obtained on the $316 \mathrm{~L}$ stainless steel substrates after heat treatment.
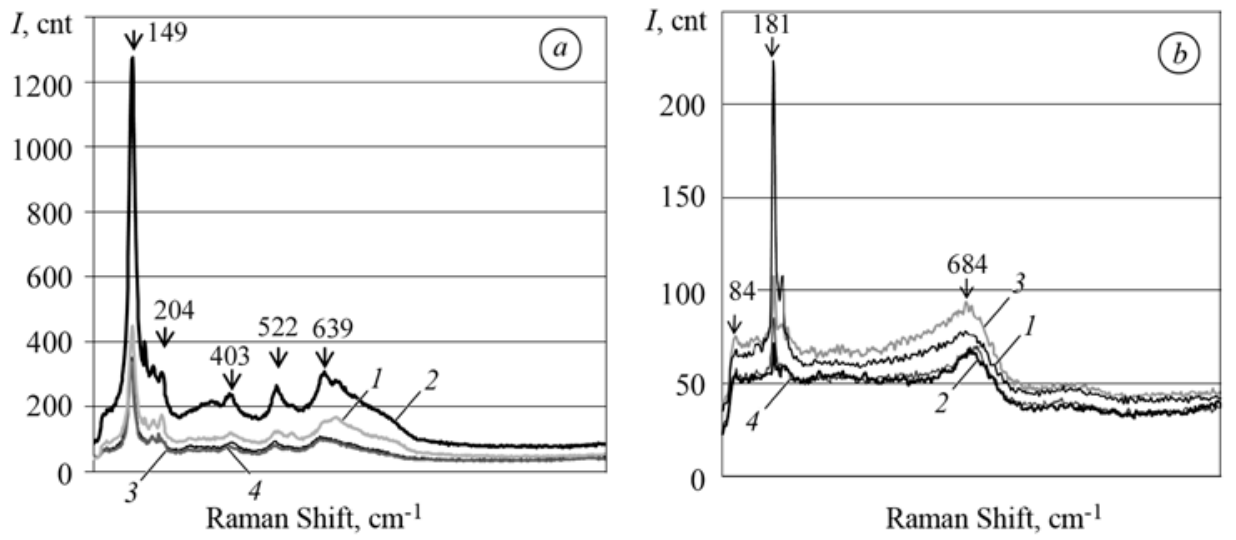

Fig. 6. Raman spectra of triple layer $\mathrm{TiO}_{2}(a)$ and $\mathrm{SiO}_{2}(b)$ coatings obtained by a dip coating technique on $316 \mathrm{~L}$ substrates from fresh, one-week-old, two-week-old and three-week-old hydrolysates.
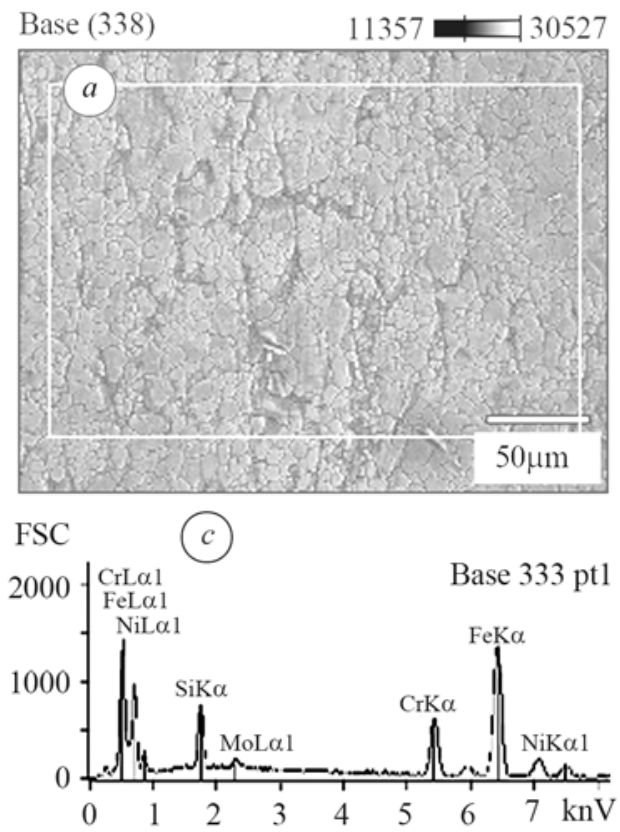

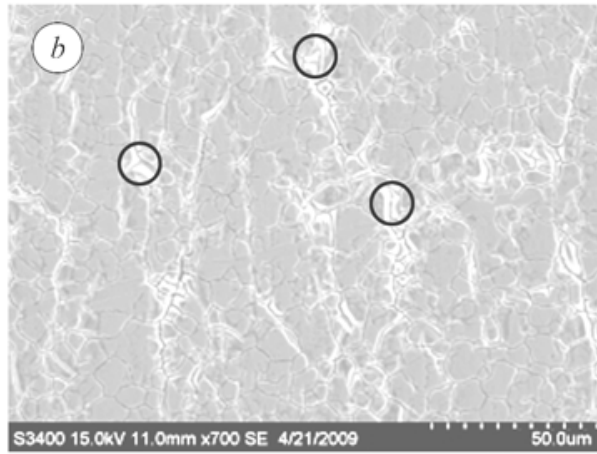

Fig. 7. SEM image showing a triple layer $\mathrm{SiO}_{2}$ coating without furrows $(a)$, triple $\mathrm{TiO}_{2}$ coating with furrows $(b)$ on $316 \mathrm{~L}$ substrate obtained by a dip coating technique and SEM-EDS analysis of range $1(c)$.

SEM analysis showed that the dip coating technique improved the continuity of the coatings, even in the case of triple layer coatings (Fig. 7). Images from SEM and EDS analysis proved that coatings obtained by this technique were continuous. SEM observations of the surface showed that $\mathrm{SiO}_{2}$ coatings were more homogeneous than $\mathrm{TiO}_{2}$ coatings. Small furrows (Fig. $7 b$ ) were localized on the surface of $\mathrm{TiO}_{2}$ coatings. The SEM-EDS analyses of the furrows (Fig. $8 a, 8 c$ ) confirmed that the pores did not penetrate the coatings. Fig. $8 b$ presents the SEM analysis of the triple layer $\mathrm{TiO}_{2}$ coating obtained by the painting technique. The coatings have numerous furrows, are much more polluted and have uneven thicknesses. In case of the triple layer coatings, the coatings' losses were localized.

The deficiency in the continuity of the single layer coatings was determined by salt spray tests (Fig. 9).

Preliminary studies of corrosion resistance (salt spray tests) for the coatings 
obtained by the painting technique on steel substrates have shown that after $24 \mathrm{~h}$ of salt spray tests the corrosion points were present and after $48 \mathrm{~h}$ almost the whole surface of samples was corroded. Prior to using the average steel substrates, samples with $316 \mathrm{~L}$ substrates were tested. Despite the total duration time being 40 days, the samples did not corrode.

SEM and SEM-EDS analyses and the analysis of the salt spray studies have confirmed that painting technique is ineffective. However, the coatings obtained by this method show minimal protective properties - the parts of substrates without the coatings corroded before the salt spray tests (Fig. $9 a$ ).
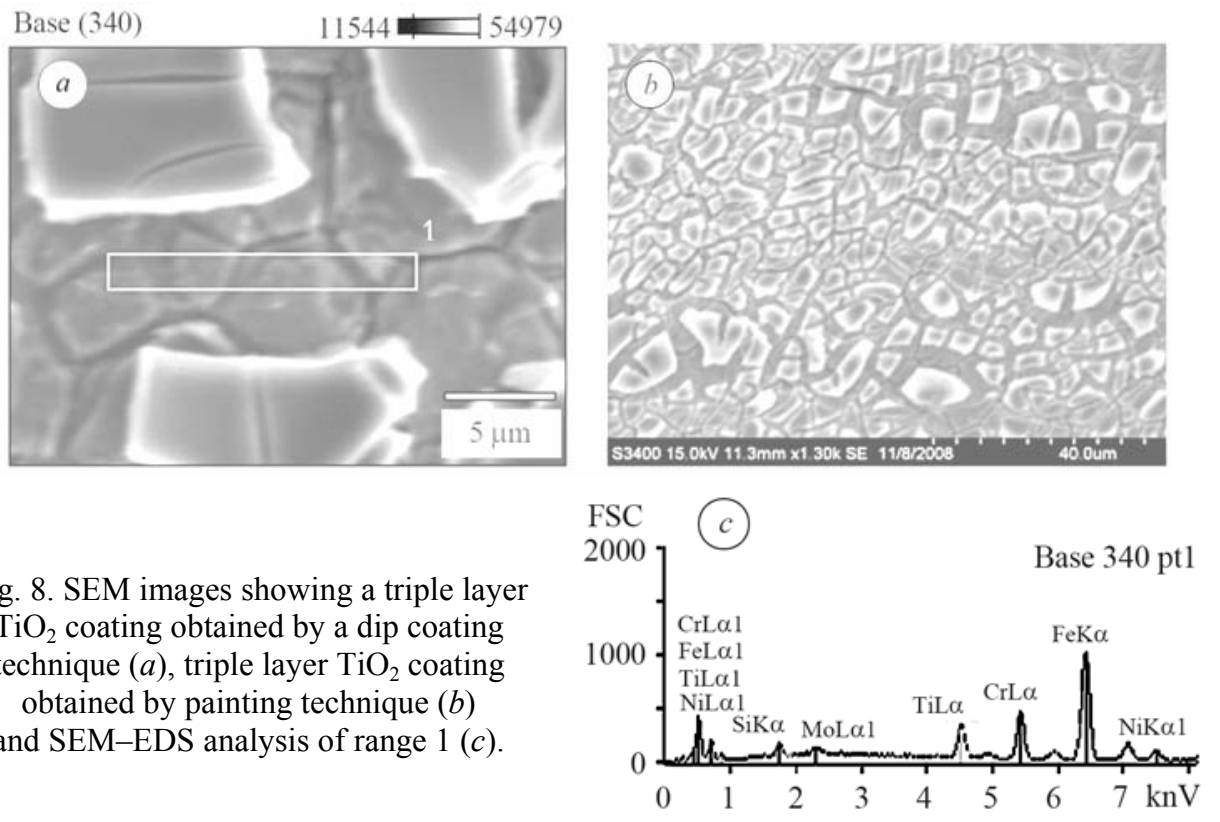

Fig. 8. SEM images showing a triple layer $\mathrm{TiO}_{2}$ coating obtained by a dip coating technique (a), triple layer $\mathrm{TiO}_{2}$ coating obtained by painting technique $(b)$ and SEM-EDS analysis of range $1(c)$.

The polarization curves of single layer and triple layer $\mathrm{SiO}_{2}$ and $\mathrm{TiO}_{2}$ coatings obtained by the dip coating technique on $316 \mathrm{~L}$ substrates from the fresh hydrolysate confirmed that the coatings behaved as corrosion barriers, showing the positive shift of the corrosion potential $E_{\text {corr }}$.

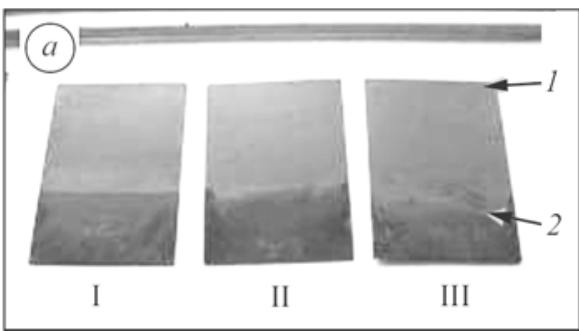

Fig. 9. Salt Spray Test for $\mathrm{SiO}_{2}$ coatings obtained by the painting technique on steel substrates: I - single layer coatings; II - double layer coatings; III - triple layer coatings. The images were taken: $a$ - before the test; $b$-after $24 \mathrm{~h} ; c$-after $48 \mathrm{~h}$ of salt spray tests, where: 1 - part with coating; 2 - part without coating.
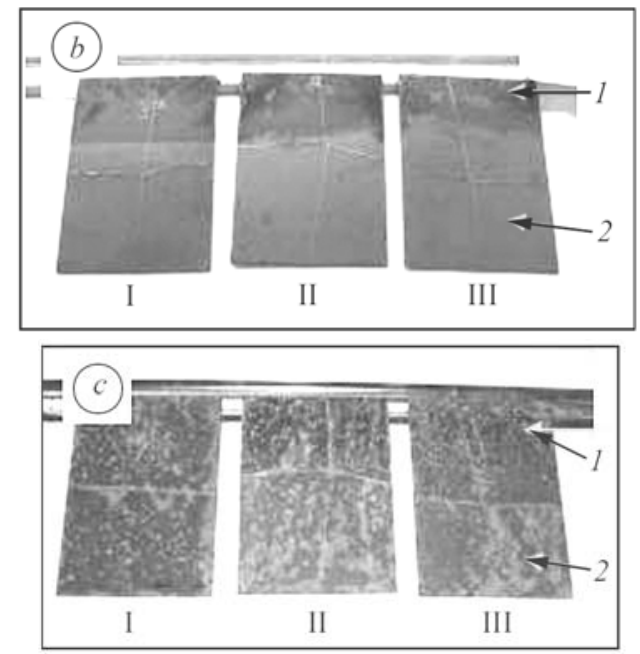

Electrochemical studies carried out for triple layer $\mathrm{SiO}_{2}$ and $\mathrm{TiO}_{2}$ coatings obtained by the dip coating method on $316 \mathrm{~L}$ substrates from the fresh, one-week-old, 
two-week-old and three-week-old hydrolysate showed that the coatings obtained from the older hydrolysate have worse protective properties (Fig. 10). To maintain good corrosion resistance of the coatings, they should be obtained from fresh hydrolysates.

SEM and SEM-EDS analyses of the samples' surfaces after tensile tests (Fig. 11) showed that single layer and triple layer $\mathrm{SiO}_{2}$ and $\mathrm{TiO}_{2}$ coatings obtained by dip coating technique on $316 \mathrm{~L}$ substrates maintained their continuity after static tensile tests. This leads to the conclusion that the coatings are at least as flexible as substrates. Moreover, local thinnings on the coatings' surface (Fig. 11a,b) were localized, which is characteristic for plastics. SEM and SEM-EDS analyses of single layer $\mathrm{SiO}_{2}$ and $\mathrm{TiO}_{2}$ coatings and triple layer $\mathrm{SiO}_{2}$ coatings obtained by the dip coating technique on 316L substrates remained continuous after the fatigue strength tests (Fig. 11c, $d$ ). Discontinuities were localized in single layer $\mathrm{TiO}_{2}$ coatings. $\mathrm{TiO}_{2}$ coatings may have lower flexibility due to their crystalline structure.
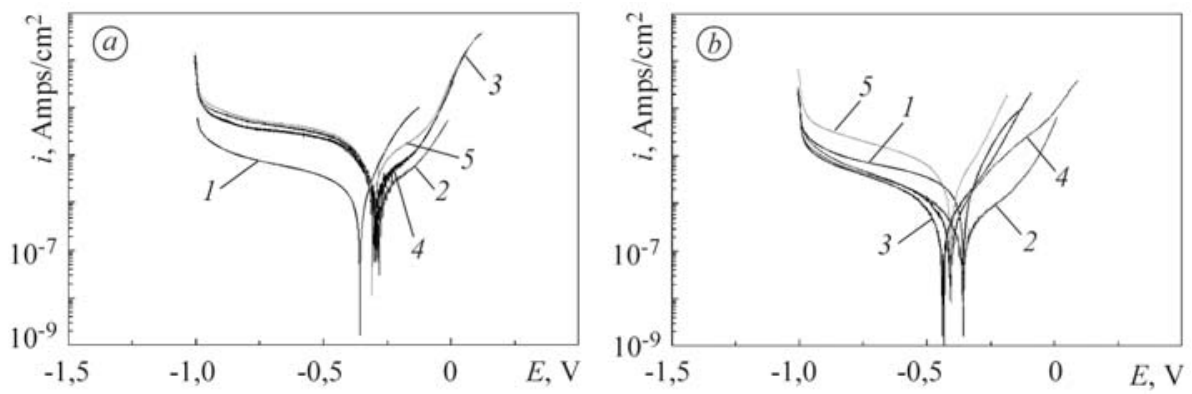

Fig. 10. Electrochemical studies of a sample without coating (1) and samples with triple layers $\mathrm{SiO}_{2}(a)$ and $\mathrm{TiO}_{2}(b)$ coatings obtained by dip coating technique on $316 \mathrm{~L}$ substrates from: 2 - fresh; 3 - one-week-old; 4 - two-week-old; 5 - three-week-old hydrolysate.
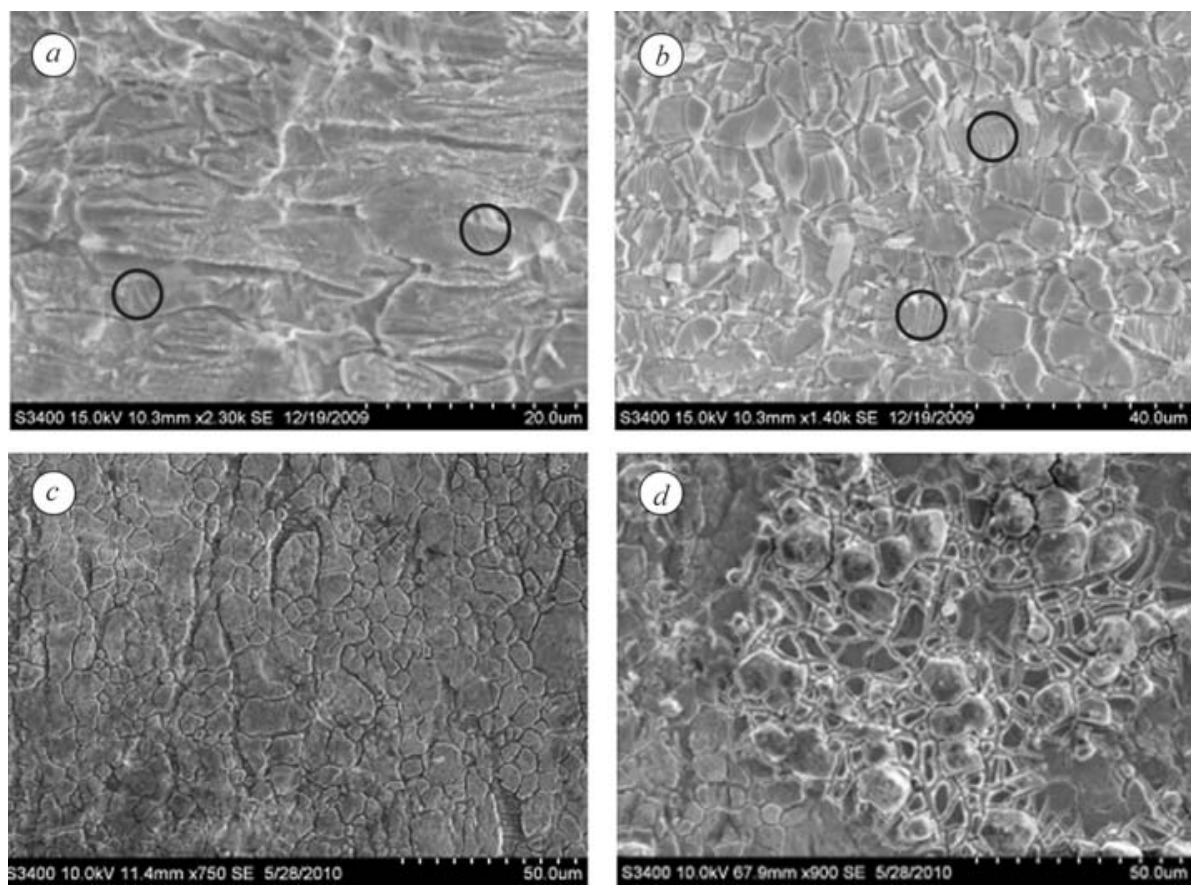

Fig. 11. SEM image showing triple layer $\mathrm{SiO}_{2}(a), \mathrm{TiO}_{2}(b)$ coatings obtained by a dip coating technique on 316L substrate after static tensile test (local thinnings are indicated by red circles).

SEM image showing triple layer $\mathrm{SiO}_{2}(c)$ and $\mathrm{TiO}_{2}(d)$ coatings obtained by a dip coating technique on $316 \mathrm{~L}$ substrate after fatigue strength tests. 


\section{CONCLUSIONS}

The SEM and SEM-EDS analyses of the sample surfaces after tensile tests have shown that the single layer and triple layer $\mathrm{SiO}_{2}$ and $\mathrm{TiO}_{2}$ coatings obtained by dip coating technique have maintained their continuity after static tensile tests and the fatigue strength tests. In single layer $\mathrm{TiO}_{2}$ coatings, however, discontinuities were localized. The $\mathrm{TiO}_{2}$ coatings may have lower flexibility due to their crystalline structure. This leads to the conclusion that the coatings (except for the single layer $\mathrm{TiO}_{2}$ ) are at least as flexible as substrates.

In conclusion, preliminary researches have confirmed that the $\mathrm{SiO}_{2}$ and $\mathrm{TiO}_{2}$ coatings obtained by the sol-gel method have physicochemical, mechanical and protective properties adequate to use them as protective coatings.

PЕЗЮМЕ. Тонкі покриви на основі $\mathrm{SiO}_{2}$ та $\mathrm{TiO}_{2}$, отримані золь-гель методом, застосовують у медицині, хімічній та харчовій промисловості. Для досягнення необхідних їх фізико-хімічних, механічних і захисних властивостей використано оптимальні режими золь-гель методу, щоб одержати покриви на основі диоксидів титану та кремнію на поверхні нержавної сталі типу 316L. Для оцінки властивостей покривів вжито методи раманівської спектроскопії, а поверхню досліджено за допомогою сканівного електронного мікроскопа. Морфологію поверхні вивчали до та після випробувань на розтяг на гідравлічній машині MTS 810 з навантаженнями до 100 kN. Встановлено, що покриви володіють необхідними фізико-хімічними та механічними властивостями, щоб їх застосовувати як захисні.

PЕЗЮМЕ. Тонкие покрытия на основе $\mathrm{SiO}_{2}$ и $\mathrm{TiO}_{2}$, полученные золь-гель методом, применяют в медицине, химической и пищевой промышленности. Для достижения необходимых их физико-химических, механических и защитных свойств применены оптимальные режимы золь-гель метода для формирования покрытий на основе диоксидов титана и кремния на поверхности нержавеющей стали типа $316 \mathrm{~L}$. Для оценки свойств покрытий использованы методы рамановской спектроскопии, а поверхность исследована с помощью сканирующего электронного микроскопа. Морфологию поверхности изучали до и после испытаний на растяжение на гидравлической машине MTS 810 с нагрузками до $100 \mathrm{kN}$. Выявлено, что покрытия владеют необходимыми физико-химическими и механическими свойствами, чтобы их применять в качестве защитных.

\section{Acknowledgement. This work was supported by grant No. S10057/I19 KBN 26.}

1. Dobrzański L. A Engineering materials and design of materials: fundamentals of materials science and metallography. - Polish. Wyd. Naukowo-Techniczne, 2006. - P. 1365-1371.

2. Maciniak J. Biomaterials. - Polish. Wyd. Politechniki Śląskiej, 2002. - P. 332-338.

3. Gluszek J. Oxide protection coatings obtained by sol-gel method. - Polish. Oficyna Wydawnicza Politechniki Wrocławskiej, 1998. - P. 12-17.

4. Active oxide materials obtained by sol-gel method: synthesis, identification and application / M. Jasiorski, B. Borak, A. Baszczuk, J. Krzak-Ros, and A. Łukowiak // Ceramics. - 2008. - Vol. 101. - P. 175-182.

5. Kłonkowski A. Sol-gel method as a low-temperature method of obtaining oxide glasses // Ceramic. - 1992. - Vol. 40. - P. 65-76.

6. Synthesis and properties of sol-gel submicron silica powders doped with iron crystallites / B. Borak, S. Laskowski, O. Heczko, et al. // J Sol-Gel Scie. Technol. - 2007. - Vol. 41. - P. 185-190.

7. Phani A. R., Gammel F. J., and Hack T. Structural, mechanical and corrosion resistance properties of $\mathrm{Al}_{2} \mathrm{O}_{3}-\mathrm{CeO}_{2}$ nanocomposities in silica matrix on $\mathrm{Mg}$ alloys by sol-gel technique // Surface \& Coatings Technology. - 2006. - Vol. 201. - P. 3299-3306.

8. Hench L. L. and West J. K. Biological applications of bioactive glasses // Life Chem. Rep. - 1996. - Vol. 13. - P. 187-241.

9. Weber J. Coating for medical implants. - United States: Patent Application 20090287301. -2009 . - P. 1-3.

10. PN-EN ISO 6892-1:2010 Metals. Tensile test. (Part 1: Room temperature test). - P. 6-46. 